\title{
POLA PENGANAN GELANDANGAN PENGEMIS (GEPENG) DI KOTA SINGARAJA, BULELENG, BALI (POTENSI SEBAGAI SUMBER BELAJAR SOSIOLOGI DI SMA)
}

\author{
Oleh: \\ Mevilia Taryo A. Dewi, I Ketut Margi, Luh Putu Sendratari \\ Program Studi Pendidikan Sosiologi \\ Jurusan Pendidikan Sejarah Sosiologi Perpustakaan \\ Universitas Pendidikan Ganesha \\ Singaraja, Indonesia \\ e-mail: mevitaryo@undiksha.ac.id, ketut.margi@undiksha.ac.id, \\ putu.sendratari@undiksha.ac.id
}

\section{PENDAHULUAN}

Kota merupakan tempat yang banyak menyuguhkan impian dan harapan bagi sebagian besar orang yang ingin memiliki hidup lebih baik terutama yang tinggal di daerah yang jauh dari perkotaan. Banyak dari mereka yang berhasil mengadu nasib di kota namun tidak sedikit pula yang harus bersusah payah untuk memenuhi kebutuhan hidup, pada akhirnya harapan yang mereka impikan tentang kota itu tidak menjadi kenyataan karena kerasnya persingan. Namun tidak hanya itu saja, kota memiliki banyak definisi yang tidak selalu tepat untuk menggambarkan suatu kota, tergantung dari mana kita melihat fokus pendekatannya. Definisi kota yang memiliki beberapa pendekatan untuk mendefinisikannya, baik dari segi pendekatan geografis-demografis, segi ekonomis dan dari segi sosioanthropologis semua itu tergantung dari mana kita akan melihat kota itu sendiri. konsep kota pun berbeda-beda tidak selalu memiliki kesamaan, di zaman sekarang tidak selalu sama dengan konsep kota dimasa mendatang.

Kota merupakan sebuah tempat tinggal yang digunakan untuk sebagian besar orang mencari pekerjaan yang layak, baik usaha dagang sendiri maupun bagi mereka yang berkerja kantoran. kota merupakan tempat tinggal bagi orang yang merantau maupun yang asli dari kota tersebut, tempat untuk bekerja mendapatkan uang maupun bagi yang memiliki usaha. Tempat pusat pemerintahan, di mana segala kegiatan pemerintahan terletak di kota. Desa dan kota memiliki perbedaan baik dari segi bangunannya maupun dari segi jumlah penduduk, hal ini merupakan karateristik kota yang membedakan dengan desa. Banyak orang yang meninggalkan kampung halaman untuk bekerja mengadu nasib di kota yang mereka anggap adalah tempat untuk melangsungkan kehidupan menjadi lebih baik. Namun dengan kurangnya bekal pengetahuan dan keterampilan membuat mereka sangat sulit untuk bertahan hidup untuk tinggal di kota, masalah yang sangat sering kita jumpai di kota-kota besar yaitu masalah kemiskinan, dimana kemiskinan merupakan sebuah kondisi seseorang tidak dapat memenuhi kebutuhannya, seperti sandang, pangan, dan papan. Hal ini dipertegas dalam 
undang-undang Nomor 13 tahun 2014 tentang penanganan fakir miskin,

a. Fakir miskin adalah orang yang sama sekali tidak memiliki sumber mata pencaharian dan/atau mempunyai sumber mata pencaharian tetapi tidak mempunyai kemampuan memenuhi kebutuhan dasar yang layak bagi kehidupan dirinya dan/atau keluarganya.

b. Kebutuhan dasar adalah kebutuhan pangan, sandang, perumahan, kesehatan, pendidikan, pekerjaan dan/atau pelayanan sosial.

Berdasarkan undang-undang di atas mengenai fakir miskin, perlunya dilakukan pensejahteran oleh pemerintah. Namun kurang meratanya dalam mensejahterakan kemiskinan baik dalam memberikan bantuan pekerjaan maupun bantuan berupa beras dan uang. Mereka berusaha untuk bekerja sendiri yang mereka mampu lakukan dengan keterampilan dan bekal yang mereka miliki, misalnya saja seperti pemulung, pengamen dan masih banyak lainnya. Tidak jarang masalah kemiskinan menjadi masalah sosial yang sangat sulit untuk diatasi misalnya saja gelandangan pengemis atau yang sering disingkat dengan (gepeng). Masih menjadi suatu masalah sosial yang sangat sulit untuk diatasi, baik dari masyarakat maupun pemerintah selain jumlahnya yang banyak, gelandangan pengemis sangat susah untuk diarahkan hidup yang layak. Di kota, aktivitas mengemis merupakan sebuah pekerjaan untuk menghasilkan uang karena sebagian besar mereka sudah nyaman menjadi gelandangan dan mengandalkan hasil uang mengemis untuk kebutuhan hidup sehari-hari.

Singaraja merupakan salah satu kota yang ada di Pulau Bali, yang letaknya di Kabupaten Buleleng. Singaraja juga tidak luput dari masalah sosial yaitu kemiskinan, salah satunya masalah sosial yaitu gelandangan dan pengemis. Gelandangan pengemis yang ada di Kota Singaraja berasal dari golongan orang dewasa, anak-anak dan orang yang sudah lanjut usia. Tidak jarang kita temui para pengemis itu melakukan aktivitas mengemis dengan menggendong anaknya semata-mata agar mendapat belas kasihan dari orang-orang yang mereka temui. Selain itu juga banyak anak-anak yang menjadi pengemis yang seharusnya seumuran mereka masih wajib mengenyam pendidikan, namun anak-anak tersebut lebih memilih menjadi pengemis karena keterbatasan ekonomi dari orang tua mereka. Hal demikian juga dilakukan oleh orang tua yang sudah lanjut usia yang seharusnya sudah tidak bekerja lagi, akhirnya menjadi pengemis untuk memenuhi kebutuhan hidupnya. Pengemis di Kota Singaraja sering ditemui di eks Pelabuhan Buleleng, Pasar Anyar, Pasar Banyuasri dan di Hardys lama yang berdekatan dengan taman kota Singaraja.

Berdasarkan data mengenai
jumlah gelandangan pengemis pada tahun 2015 dan 2016 yang didapat dari dinas sosial mengalami penurunan, yang awalnya hanya 23 menjadi 15 orang. Tidak hanya dari segi jumlah yang berkurang, dari data ini terlihat bahwa jumlah anak-anak dan jumlah perempuan masih terlihat sangat banyak. Tidak hanya itu saja mereka berasal dari satu daerah yang berada di Bali yaitu Desa Munti Gunung, Kecamatan Kubu, Kabupaten Karangasem yang masih mendominasi. Dapat dilihat pada data jika data mengalami penurunan tapi masih ada gelandangan pengemis yang datang ke Kota Singaraja. Dalam data tahun 20152016 orang yang datang lebih sedikit dan orangnya pun berbeda namun persamaan yang ada disini yaitu tentang asal mereka, yaitu dari Desa Munti Gunung yang terletak di Kabupaten Karangasem.

Fenomena gelandangan dan pengemis di Kota Singaraja membuat peneliti untuk lebih mendalami mengenai faktor penyebab adanya gelandangan dan pengemis, dikarenakan setiap gelandangan dan pengemis memiliki faktor penyebab berbeda-beda yang mendorong mereka untuk menjadi gelandangan dan pengemis, kemudian pola penanganan gelandangan dan 
pengemis yang dilakukan oleh Dinas Sosial Kabupaten Buleleng, serta persepsi gelandangan dan pengemis terhadap pola penanganan yang dilakukan oleh Dinas Sosial terhadap keberadaan mereka saat ini.

Sumber belajar adalah segala sesuatu yang ada dilingkungan kita yang dapat di gunakan sebagai proses belajar mengajar, yang secara fungsional digunakan sebagai optimalisasi hasil belajarnya Wina (2008). Saat memberikan materi pembelajaran sosiologi guru hanya berpedoman pada lembar kerja siswa (LKS) dan buku ajar, sehingga peserta didik tidak peka terhadap permasalahan sosial yang ada di lingkungan sekitarnya. Dapat dilihat bahwasannya banyak sekali permasalahan sosial yang bisa dijadikan sumber belajar sosiologi, salah satunya yaitu fenomena gelandangan dan pengemis yang ada di Kota Singaraja yang memiliki kaitan dengan materi permasalahan sosial di kelas XI. Sehingga hal ini membuat sangat menarik untuk di teliti.

Berdasarkan penjelasan diatas peneliti akan membuat hasil penelitian, berjudul. "POLA PENGANAN GELANDANGAN PENGEMIS (GEPENG) DI KOTA SINGARAJA, BULELENG, BALI (POTENSI SEBAGAI SUMBER BELAJAR SOSIOLOGI DI SMA)"

Penelitian ini dapat dikaji dengan menggunakan beberapa teori, yaitu:

(1) teori gelandangan dan pengemis, Menurut Poerwadarminta (dalam muslim, 2013:26) Gelandangan merupakan keadaan orang-orang yang tidak sesuai dengan norma dan kehidupan yang layak dalam masyarakat, dan tidak memiliki tempat tinggal dan pekerjaan yang tetap diwilayah tertentu, hidupnya mengembara ditempat-tempat umum, dan berpindahpindah tempat. Menurut Sarlito W. Sarwonlo (dalam muslim, 2013:26) gelandangan adalah orang miskin tinggal di kota-kota yang tidak mempunyai tempat tinggal yang tetap dan tempat tinggal yang sah menurut hukum. Hal ini menjadi beban pemerintah kota karena ikut menikmati fasilitas perkotaan, tetapi tidak membayar kembali fasilitas perkotaan seperti halnya pajak. Gelandangan memiliki ciri-ciri tersendiri orang tersebut dikatakan gelandangan atau tidak, hal ini diperkuat dengan penjelasan (Muslim, 2013:28) menyatakan,

a. Anak sampai usia dewasa, tinggal disembarang tempat dan hidup mengembara atau mengelandang di tempat-tempat umum, biasanya di kota-kota besar.

b. Tidak mempunyai tanda pengenal atau identitas diri, berperilaku kehidupan bebas atau liar.

c. Tidak mempunyai pekerjaan tetap, meminta-minta atau mengambil sisa makanan atau barang bekas.

(2) Pengemis adalah seorang yang mendapat penghasilan dari hasil memintaminta kepada orang lain dengan berbagai cara agar mendapat belas kasihan dari orang lain (LP3ES, 1986:7).

Menurut Perda Nomer 12 tahun 2008 pengemis adalah orang yang mendapat penghasilan dari memintaminta kepada orang lain dimuka umum dengan mengharapkan belas kasihan dari orang lain. Keith Hart (dalam Muslim, 2013:27) mengemukakan bahwa dari kesempatan memperoleh penghasilan yang sah pengemis dan gelandangan termasuk dalam pekerja disektor informal. Pengemis memiliki cirri-ciri tersendiri orang yang di katakana sebagai pengemis berikut ini merupakan ciri-ciri dari pengemis, hal ini diperkuat dengan penjelasan (Muslim, 2013:28) menyatakan,

a. Berdiri di tengah matahari dengan cucuran keringat.

b. Menunjukan bukti bahwa mereka cacat, misalnya dengan tidak menggunakan baju atau menggulung celananya.

c. Duduk atau mengeletak di tengah jalan, di antara mobil-mobil, sehingga menimbulkan lebih banyak perhatian bagi pengemudi agar tidak menabrak mereka dan lebih memudahkan pengendara memberikan uang. 
d. Menggendong anak kecil atau langsung menggunakan anak kecil untuk mengemis.

e. Tampil beda dengan membawa sebuah karto yang bertuliskan mereka membutuhkan biaya sekolah atau biaya hidup.

(3)Faktor Penyebab Adanya Gelandangan dan Pengemis Banyak faktor seorang untuk hidup mengelandang salah satunya merupakan faktor ekonomi yang belum mencapai taraf hidup kesejahterahan sosial yang baik sehingga meningkatnya gelandangan dan pengemis di kota-kota besar (Muslim, 2013: 27). Menurut Noer Effendi (dalam Muslim, 2013: 27) munculnya gelandangan disebabkan oleh beberapa faktor, antara lain:

a. Faktor eksternal, antara lain:

1. Gagal dalam mendapatkan
pekerjaan.

2. Terdesak oleh keadaan, seperti tertimpa bencana alam, perang.

3. Pengaruh orang lain

b. Faktor internal, antara lain:

1. Kurang bekal pendidikan dan keterampilan.

2. Rasa rendah diri, rasa kurangpercaya diri, kurang siap untuk hidup di kota besar.

3. Sakit jiwa, cacat tubuh.

(3) Teori Pola Penanganan Gelandangan dan pengemis

Penanganan merupakan suatu pencegahan segala upaya yang dilakukan agar tidak terjadi. Sebisa mungkin untuk dihindari, menghidari segala sesuatu dari kerusakan, yang terjadi pada diri seseorang ataupun masyarakat yang dapat mengalami kerugian. Seperti halnya mencegah banyaknya gelandangan pengemis yang ada di Kota Singaraja, bagaimana pemerintah dalam menangani hal ini, apakah bantuan fiansial ataupun bantuan pembinaan berwirausaha, tidak banyak lagi gelandangan pengemis yang ada di Singaraja. Gelandangan dan pengemis menjadikan hal ini sebuah pekerjaan yang menghasilkan bagi mereka Sarlito W. Sarwono (dalam Agastya, 2015). Penanggulangan merupakan cara untuk mengatasi peristiwa yang telah terjadi di masyarakat. Menurut peraturan pemerintah Republik Indonesia No. 31 tahun 1980 (dalam Muslim, 2013:28) diatur usaha pemerintah untuk menangani masalah sosial, gelandangan dan pengemis yang dilakukan dengan cara sebagai berikut.

1. Usaha preventif merupakan pengendalian sosial usaha mencegah segala sesuatu yang mungkin terjadi, usaha ini di lakukan secara terorganisir baik di lakukan secara perorangan maupun kelompok yang meliputi penyuluhan, bimbingan, latihan, pendidikan, pemberian bantuan, pengawasan, serta pembinaan lanjut kepada berbagai pihak yang ada hubungannya dengan pergelandangan dan pengemisan. Usaha ini bertujuan untuk mencegah timbulnya gelandangan dan pengemis di masyarakat, dan dapat di terapkan dalam kehidupan mereka selanjutnya Usaha preventif ini dilakukan dengan cara (a) Penyuluhan dan bimbingan sosial (b) Pembinaan sosial (c) Bantuan sosial (d) Perluasan kesempatan kerja (e) Pemukiman local (f) Peningkatan derajat kesehatan.

2. Usaha represif adalah usaha-usaha yang terorganisir, baik melalui lembaga maupun bukan lembaga. Usaha represif ini memiliki tujuan untuk mengurangi atau mentiadakan gelandangan dan pengemis, usaha ini lebih kepada penekanan, mengekang perorangan maupun suatu kelompok agar tidak lagi kembali mengemis, biasanya usaha ini dilakukan dengan cara (a) Razia (b) Penampungan sementara untuk diseleksi setelah gelandangan dan pengemis tersebut dirazia dan diseleksi, maka tindakan selanjutnya dilepaskan dengan syarat, dimasukkan dalam panti sosial, dikembalikan kepada keluarganya, diserahkan ke 
pengadilan, diberikan pelayanan kesehatan.

3. Usaha rehabilitatif adalah usahausaha yang terorganisir, merupakan usaha pemulihan kemampuan dan penyaluran kembali ke daerah pemukiman, atau kampung halaman masing-masing dimana mereka tinggal sejak awal seperti halnya yang di lakukan oleh Dinas Sosial dalam menanganai permasalahan sosial seperti gelandangan dan pengemis.

(4) Teori Persepsi

Menurut Sarlito W. Sarwono (dalam Rohmaul dan Yudi, 2013:104), persepsi merupakan proses perolehan, penafsiran, pemilihan dan pengaturan informasi indrawi. Persepsi ini berlangsung pada saat seseorang menerima stimulus yang terdapat dari dunia luar yang ditangkap oleh organorgan bantu kemudian masuk ke dalam otak, disini persepsi merupakan proses dimana pencarian informasi untuk dipahami yang menggunakan alat indera.

Persepsi menurut Salmaniah (2014:11) yang mengemukakan bahwasannya persepsi merupakan "suatu proses pengamatan yang berasal dari suatu kognisi secara terus menerus dan dipengaruhi oleh informasi baru dari lingkungan". Faktor-faktor yang mempengaruhi persepsi menurut Sarlito W. Sarwono (dalam Rohmaul dan Yudi, 2013:104) yaitu:

a. Perhatian, biasanya tidak menangkap seluruh rangsang yang ada disekitar kita sekaligus, tetapi memfokuskan perhatian pada satu atau dua objek saja. Perbedaan fokus perhatian antara satu dengan orang lain akan menyebabkan perbedaan persepsi.

b. Kesiapan mental seseorang terhadap rangsangan yang akan timbul.

c. Kebutuhan merupakan kebutuhan sesaat maupun menetap pada diri individu akan mempengaruhi persepsi orang tersebut. Kebutuhan yang berbeda akan menyebabkan persepsi bagi tiap individu. d. Sistem nilai, yaitu sistem nilai yang berlaku dalam suatu masyarakat juga berpengaruh pula terhadap persepsi.

e. Tipe kepribadian, yaitu dimana pola kepribadian yang dimiliki oleh individu akan menghasilkan persepsi yang berbeda.

(5) Teori Sumber Belajar

Menurut Wina (2008) Sumber belajar adalah segala sesuatu yang ada dilingkungan kita yang dapat di gunakan sebagai proses belajar mengajar, yang secara fungsional digunakan sebagai optimalisasi hasil belajarnya. Optimalisasi tidak hanya dilihat dari hasil belajarnya (output) melainkan dapat dilihat dari keseharian mereka dengan berbagai sumber yang dapat merangsang siswa untuk belajar dan mempercepat pemahaman dan penguasaan dibidang ilmu lainnya yang mereka pelajari.

Menurut Wina (2008) selain memiliki pengertian dan manfaat, sumber belajar memiliki jenis-jenis yang dapat diggunakan dalam proses belajar. AECT (Association for Education Communication and Technology) membedakan enam jenis sumber belajar yang dapat diggunakan dalam proses belajar seperti :

1. Pesan (Message)

2. Orang (People)

3. Bahan (Matterials)

4. Alat

5. Teknik (Tehnique)

6. Latar (Setting)

Tujuan penelitian ini untuk mengetahui; (1) faktor penyebab munculnya gelandangan dan pengemis di Kota Singaraja, (2) bagaimana pola penganganan pemerintah serta Dinas Sosial Kota Singaraja terhadap gelandangan pengemis yang masih banyak dijumpai disudut Kota Singaraja, (3) persepsi gelandangan pengemis terhadap upaya penanganan yang telah di lakukan oleh Dinas Sosial Kota Singaraja, (4) aspek-aspek gelandangan pengemis di Kota Singaraja untuk dijadikan sumber belajar Sosiologi di SMA.

\section{METODE}




\begin{abstract}
Metode yang digunakan yaitu metode deskriptif kualitatif untuk memperoleh informasi mengenai gelandangan dan pengemis. Mendeskripsikan dan menganalisis mengapa terdapat fenomena gelandangan pengemis di kota Singaraja, bagaimana pola penanganan gelandangan pengemis yang dilakukan oleh dinas sosial selaku sebagai penagung jawab permasalahan sosial ini, aspek apa yang memiliki kaitan dalam sumber belajar sosiologi di SMA masalah gelandangan pengemis yang terjadi di Kota Singaraja, Buleleng, Bali.
\end{abstract}

Sumber data yang dapat digunakan dalam penelitian deskriptif kualitatif sebagai berikut (1) Narasumber, dalam penelitian ini yang menjadi narasumber atau informan adalah gelandangan dan pengemis, Kepala Dinas Sosial, Kepala Satpol PP dan guru SMA N 1 SUKASADA; (2) Aktivitas, dalam penelitian ini aktivitas yang dilakukan oleh informan di pinggir jalanan, kantor dinas, dan sekolah; (3) Tempat atau lokasi, penelitian ini berlokasi di Jalan Ahmad Yani; (4) Gambar dan dokumen, dalam mendapatkan data dengan mengambil gambar peristiwa atau kejadian yang diteliti, sedangkan untuk dokumen peneliti menggunkan jenis data kuatitaif berupa data gelandangan dan pengemis, aktivitas gelandangan dan pengemis sebagai penunjang data kualitatif yang didapatkan dengan demikian memberikan bukti nyata dari hasil penelitian yang dilakukan.

Demi mendapatkan data yang relevan tidak semua orang dapat digunakan sebagai informan dalam penelitian ini. pada penelitian ini peneliti menggunakan teknik purposive sampling dan teknik snowball hal ini bertujuan agar data yang diperoleh peneliti bisa lebih akurat dan jelas.

Dalam teknik pengumpulan data, peneliti menggunakan metode observasi non partisipatif Peneliti tidak ikut serta dalam kegiatan penelitian, seperti halnya kehidupan sehari-hari secara langsung namun dalam penelitian ini peneliti hanya mengamati bagaimana berlangsungnya gelandangan dan pengemis dalam melakukan kegiatan mengemis dan bagaimana cara mereka. Kemudian untuk teknik wawancara ditujukan kepada gelandangan dan pengemis, kepala Dinas Sosial dan Satpol PP. Hal ini memiliki tujuan agar mengetaui faktor penyebab menjadi gelandangan dan pengemis, pola penanganannya yang dilakukan pemerintah, persepsi gelandangan terhadap penanganan Dinas Sosial. Kemudian yang terakhir melakukan studi dokumen.

Menurut Miles dan Huberman dalam (Sugiyono, 2010:337) teknik analisis data yang dilakukan dalam penelitian kualitatif harus dilaksanakan secara terus-menurus sampai data yang dicari tuntas dan jenuh. Dalam teknik analisis data terdapat beberapa aktivitas yang dilakukan, yaitu: (1) Reduksi Data. Dalam penelitian ini, peneliti memilih halhal yang dianggap peting dan membuang hal-hal yang tidak penting dalam penelitian. (2) Penyajian Data. Dalam langkah ini data yang diperoleh disajikan dalam bentuk uraian singkat. (3) Penarikan Kesimpulan. Langkah yang terakhir yang dilakukan dalam teknik analisis data. Kesimpilan awal yang dipaparkan oleh peneliti dalam penelitian kulaitatif merupakan kesimpulan yang dapat bersifat sementara.

Dalam penelitian ini untuk mendapatkan keabsahan data, agar penelitiannya diakui kebenarannya secara objektif, penelitian ini menggunakan teknik triangulasi teknik dan triangulasi sumber.

\section{HASIL DAN PEMBAHASAN}

\section{Faktor Penyebab Fenomena Gelandangan dan Pengemis}

Faktor penyebab adanya fenomena gelandangan dan pengemis di Kota Singaraja Kabupaten Buleleng Bali, dapat dilihat dari dua sisi yaitu faktor internal dan faktor eksternal Menurut Noer Effendi (dalam Muslim, 2013:29). faktor internal sendiri meliputi kurangnya bekal dan keterampilan, rasa rendah diri, rasa kurang percaya diri, kurang siap untuk 
hidup di kota besar, sakit jiwa, cacat tubuh. Sedangkan faktor eksternalnya sendiri yaitu gagalnya dalam mendapat pekerjaan, terdesak oleh keadaan seperti tertimpa bencana alam dan yang terakhir merupakan pengaruh oranglain. Namun tidak semua aspek dapat dijadikan penyebab munculnya fenomena gelandangan, dengan kata lain faktor penyebab munculnya fenomena gelandangan pengemis sangat tergantung pada situasi maupun alasan masingmasing individu yang memilih pekerjaan tersebut.

Persaingan hidup yang keras di kota membuat mereka yang tidak memiliki bekal pendidikan dan keterampilan, banyak orang yang menganggap hidup di kota lebih menjanjikan dibandingkan hidup di desa, apalagi di kota sebagai pusat perekonomian, kebudayaan, politik dan pusat pemerintahan maka dari itu tidak sedikit masyarakat desa yang memilih pindah ke kota, yang diharapkan dapat merubah nasib. Tidak sedikit dari mereka yang gagal mendapatkan pekerjaan karena kurangnya keterampilan yang mereka miliki, berujung pada pengangguran, kemiskinan dan pada akhirnya mereka lebih memilih hidup mengelandang dari meminta-minta karena menurut mereka hanya hal itu yang mereka dapat lakukan untuk memenuhi kebutuhan hidup sehari-hari. Seperti yang alami oleh Ibu Wayan (47tahun) dan Ibu Sari (30tahun) mengatakan bahwasannya memilih sebagai gelandangan dan pengemis kurangnya memiliki bekal pendidikan dan keterampilan yang mereka miliki selama masa mudanya. Hal ini juga serupa dibenarkan oleh Wayan Ardika (17 tahun) dan Kadek Sonny (14tahun) yang lebih mengorbankan pendidikan hanya untuk datang kekota membantu orangtua mereka yang ada di kampung.

$\begin{array}{ccc}\text { Gagal } & \text { dalam mendapatkan } \\ \text { pekerjaan merupakan salah satu } & \text { san } \\ \text { penyebab } & \text { banyaknya } & \text { muncul }\end{array}$ gelandangan pengemis di Kota Singaraja, ini memiliki kaitannya dengan kurangnya dari mereka yang tidak memiliki keterampilan yang lebih dan kurangnya bekal pendidikan yang mereka miliki membuat mereka lebih memilih menjadi gelandangan pengemis, di sisi lain daya saing sumber daya manusia yang di butuhkan dalam hal bidang-bidang tertentu beraneka ragam dan kebanyakan masyarakat desa yang memiliki keterbatasan tidak dapat mengikuti persaingan yang ada di kota-kota besar, hal ini menyulitkan mereka dalam memperoleh pekerjaan yang layak, dan pada akhirnya mereka memilih jalan pintas yang di fikirnya lebih muda. Hal ini seperti yang dialami oleh Bapak Gede Sedana (47tahun) dan Ibu Sari (30tahun) mengatakan bahwasannya merasa kesulitan mendapatkan pekerjaan sehingga memilih menjadi gelandangan dan pengemis dengan keterbatasan mereka miliki.

\section{Pola Penanganan Gelandangan Pengemis oleh Pemerintah}

Pola pengangan gelandangan
pengemis yang di lakukan oleh
Pemerintah Kabupaten Buleleng. Pola
penanganan ini merupakan bagian dari
upaya agar tidak lagi muncul
permasalahan sosial yang ada
dimasyarakat, menurut Peraturan Pemerintah Republik Indonesia No 31 tahun 1980 (dalam muslim, 2013) meliputi beberapa usaha untuk menangani permasalahan sosial gelandangan pengemis yaitu usaha Represif, dan rehabilitative.

Usaha yang di lakukan oleh Dinas Sosial dalam mengatasi dan menanggulangi adanya gelandangan dan pengemis memang sangat sulit, dan ini menjadi permasalahan sosial yang sangat sulit di atasi oleh Dinas Sosial setiap tahunnya. Biasanya Dinas Sosial melakukan tindakan secara represif yang di lakukan dengan cara merazia para gelandangan dan pengemis setiap beberapa bulan sekali jika dianggap oleh Dinas Sosial bahwa gelandangan dan pengemis mulai mengganggu pemandangan kota (Soedjono,1974: 30). Dinas Sosial mulai melakukan penangkapan di bantu dengan Satpol PP dan Polisi kemudian setelah di lakukan 
penangkapan gelandangan dan pengemis di bawa ke kantor Dinas Sosial menggunakan mobil Satpol PP, lalu di lakukan pendataan kemudian setelah di lakukan pendataan oleh Dinas Sosial. Hal ini disampaikan oleh Emi selaku Kepala Bidang Pelayanan dan Rehabilitasi Sosial dan Bapak Putu Sukayadnya selaku Kepala Bidang trantip mengatakan bahwaannya mereka melakukan kerja sama dalam proses penangkapan gelandangan dan pengemis.

Usaha lain yang di lakukan oleh Pemerintah untuk menangani gelandangan dan pengemis yang ada di Kota Singaraja setelah melakukan razia, mereka dibawa ke kantor Dinas Sosial untuk dilakukannya pendataan sebelum pada akhirnya di beri bimbingan oleh petugas Dinas sosial. bimbingan terhadap mereka, hal ini termasuk kedalam pendekatan preventif, dimana pendekatan yang di lakukan lebih kedalam pendekatan dengan cara membimbing, membina, dan melakukan penyuluhan. Hal ini disampaikan oleh lbu Emi selaku Kepala Bidang Pelayanan dan Rehabilitasi Sosial sudah memberikan pengarahan, terhadap pekerjaan menjadi pengemis yang mereka tekuni, masih banyak pekerjaan layak yang mereka dapat lakukan selain menjadi gelandangan pengemis yang ada di desa mereka dan membahayakan diri mereka, terlebih lagi banyak dari mereka yang mendominasi yaitu perempuan dan anakanak dibawah umur.

Setelah dilakukannya razia oleh Dinas Sosial dan Satpol PP, setelah itu mereka melakukan bimbingan untuk menghimbau agar mereka tidak lagi datang ke kota untuk hidup mengelandang dan jadi pengemis, selanjutnya usaha yang dilakukan oleh Dinas Sosial dan dibantu oleh Satpol PP yaitu pemulangan kembali ke daerah asalnya, ke kampung halaman mereka masing-masing. Hal ini disampaikan oleh pengemis bernama Wayan Ardika (17tahun) dan Ibu Sari (30tahun) mengatakan bahwasannya setelah ditangkap, lalu diberi bimbingan dan dipulangkan ke kampung halaman masing-masing dengan diantar oleh petugas Dinas Sosial dan petugas Satpol PP.

\section{Persepsi Gelandangan Pengemis Terhadap Pola Penanganan Dinas Sosial}

Dalam menangani gelandangan dan pengemis khususnya dari dinas sosial memiliki pola penanganan yang beranekaragam. Namun upaya-upaya yang di lakukan Dinas Sosial ini tidak selalu berjalan mulus masih saja ada anggapan-anggapan dari mereka yang menilai bahwasannya kita ini akan baikbaik saja, dapat menjaga diri dari bahaya yang mengincar mereka, berbeda dengan Dinas Sosial yang mengkhwatirkan keberadaan mereka. Persepsi itu sendiri muncul pada saat seseorang itu menerima stimulus dari alat indera yang kemudian stimulus tersebut di terima oleh fikirian yang pada akhirnya membentuk sebuah persepsi, mengenai apa yang mereka terima Sarlito W. Sarwono (dalam Rohmaul dan Yudi, 2013:104). Sama seperti halnya pada saat gelandangan dan pengemis terjaring razia, bagaimana petugas Satpol PP, Polres dan petugas dari Dinas Sosial itu sendiri memperlakukan gelandangan dan pengemis tersebut, dan yang pasti mereka memliliki sudut pandang dan persepsi masing-masing terhadap pola penanganan Pemerintah yang mereka rasakan, sudah layak apa ada hal lain yang perlu di benahi, karena peran gelandangan dan pengemis sebagai penerima stimulus atau rangsangan tersebut, yang di dapat dari petugas yang merazia mereka. Yang disampaikan oleh Ibu wayan (47tahun) sebagai pengemis, dan Bapak Gede Sedana (47tahun) sebagai pengemis, menyampaikan persepsi mereka terhadap pola penanganan yang dilakukan pemerintah dalam menangani permasalahan sosial ini, terkadang perlakuan mereka tiba-tiba mengagetkan, dan tegas pada saat merazia, penanganan sudah cukup baik, tidak ada masalah pada pola penanganan gelandangan dan pengemis dengan pemerintah. 


\section{Aspek-aspek Fenomena Gelandangan dan Pengemis Yang Dapat Digunakan Sebagai Sumber Belajar Sosiologi di SMA}

\section{Ranah Kognitif}

ranah kognitif sendiri yang meliputi aspek-aspek yaitu pengetahuan, penalaran dan pemikiran dalam kegiatan belajar mengajar. Jika di kaitkan dengan kurikulum 2013 maka terdapat pada KI 3 sebagai berikut : memahami, menerapkan, menganalisis dan mengevaluasi pengetahuan filsafat, konseptual, procedural, dan metakognitif berdasarakan rasa ingin tahunya tentang ilmu pengetahuan, teknologi, seni, budaya, dan humaniora dengan wawasan kemanusiaan, kebangsaan, kenegaraan, dan peradaban terkait penyebab fenomena dan kejadian, serta menerapkan pengetahuan procedural pada bidang kajian yang spesifik sesuai dengan bakat dan minatnya untuk memecahkan masalah.Kemudian dalam kaitannya dengan $\mathrm{KI} 3$ yang sesuai dengan silabus Kementrian Pendidikan dan Kebudayaan Jakarta 2016 yaitu memanfaatakan hasil penelitian terhadap pola penanganan gelandangan dan pengemis di Kota Singaraja sebagai buku sumber belajar Sosisologi di SMA, dalam hal ini siswa dapat memahami, menerapkan serta dapat menganalisis.

\section{Ranah Afektif}

Aspek yang berkaitan dengan sikap perasaan, emosi, dan reaksi berbeda dengan penalaran merupakan bagian dari ranah afektif. Hal ini sesuai dengan penjelasan pada Kopetensi Inti (KI) I dan II. KI I: menghayati dan mengamalkan ajaran agama yang dianutnya, sedangakn $\mathrm{KI} 2$ : menghayati dan mengamalakn perilaku jujur, disiplin, tangung jawab, peduli (gotong royong, kerjasama, toleransi, damai), santun, responsive, dan pro-aktif. mengenai $\mathrm{KI} \mathrm{I}$ dan 2 di atas yang menegaskan bahwasannya pola penanganan gelandangan dan pengemis yang di lakukan oleh Pemerintah di Kota Singaraja potensi sebagai buku sumber sosiologi di SMA yang memiliki kaitannya dengan materi permasalahan sosial di masyarakat, hal ini dapat membantu siswa mendapat pemahaman bahwasannya gelandangan dan pengemis dapat di jadikan contoh dari materi masalah sosial di masyarakat, masalah sosial merupakan suatu ketidak sesuaian unsur-unsur yang ada di dalam masyarakat, terjadi perbedaan yang sangat mencolok antara nilai-nilai yang ada di masyarakat dengan realita misalnya saja faktor yang mempengaruhi salah satunya yaitu ekonomi menyebabkan kemiskinan, pengangguran dan masih banyak lagi faktornya misalnya saja seperti budaya, biologis dan psikologis. Dari ke 4 faktor ini menjadi penyebab munculnya permasalahan sosial di masyarakat. Gelandangan dan pengemis dapat dijadikan sebagai contoh pembelajaran, dikarenakan hal ini merupakan bagian dari permasalahan sosial yang ada di masyarakat dan mencakup faktor ekonomi, dan permasalahan ini sangat sulit diatasi. Banyak di luar sana orang-orang yang mengalami kesulitam ekonomi, dan harus saling membantu dalam permasalahan ini.

\section{Ranah Psikomotor}

Psikomotor merupakan ranah yang terakhir, dalam ranah ini melibatkan aspek keterampilan jasmani. Dalam kurikulum 2013 ranah psikomotor ini sesuai dengan $\mathrm{KI} 4$, dimana dalam $\mathrm{KI} 4$ memiliki penjelasan yaitu, mengolah, menalar, dan menyajikan dalam ranah konkrit dan ranah abstrak terkait dengan pengembangan dari yang dipelajarinya di sekolah secara mandiri dan mampu menggunakan metode sesuai dengan kaidah keilmuan. Hal ini jika di kaitkan dengan $\mathrm{KI} 4$ dengan pola penanganan gelandangan dan pengemis di Kota Singaraja memiliki potensi sebagai sumber belajar sosilogi di SMA, peserta didik di harapkan untuk mampu mengaitkan permasalahan sosial yang ada di masyarakat dengan realita sosial yang ada dan dengan menggunakan 
konsep-konsep dasar sosiologi untuk mengetahui lebih dalam beberapa bentuk permasalahan sosial yang ada di masyarakat.

\section{SIMPULAN DAN SARAN}

Berdasarkan data yang diperoleh, dapat disimpulkan sebagai berikut.

1. faktor penyebab fenomena gelandangan dan pengemis di Kota Singaraja selian faktor ekonomi ada faktor lain yaitu faktor internal dan faktor eksternal yang menjadi penyebab munculnya gelandangan dan pengemis. Adapun faktor internal sendiri meliputi kurangnya bekal pendidikan dan keterampilan, rendahnya kesadaran mereka akan pentingnya mengenyam pendidikan membuat mereka lebih mementingkan untuk mengesampingkan pendidikan, sehingga mereka tidak memiliki bekal apapun baik pendidikan maupun keterampilan untuk membantu kelangsungan hidup. Sedangkan faktor eksternalnya yaitu gagalnya mendapat pekerjaan dimana tingkat persaingan ketat dalam mendapatkan pekerjaan di Kota-kota besar membuat mereka yang rendah pendidikan dan keterampilan menjadi kesulitan dalam mendapatkan pekerjaan yang layak dan pada akhirnya memutuskan untuk hidup mengelandang dan mengemis ke Kota Singaraja yang dianggap dapat menjamin kelangsungan hidup mereka kedepan.

2. Pola penanganan yang lakukan pemerintah terhadap gelandangan dan pengemis untuk mengurangi jumlah gelandangan dan pengemis yang ada di Kota Singaraja, Kabupaten Buleleng. Adapun usaha yang dilakukan Pemerintah Kota Singaraja dalam menangani permasalahan gelandangan dan pengemis yaitu usaha represif, preventif, kemudian rehabilitatif.
Usaha represif merupakan usaha yang terorganisir dan dilakukan oleh instansi resmi yaitu Dinas Sosial dibantu dengan Satpol PP usaha ini bertujuan untuk mengurangi gelandangan dan pengemis yang ada di Kota Singaraja dengan cara merazia keberadaan mereka setelah di razia dengan di bantu oleh Satpol PP, mereka diajak ke kantor Dinas Sosial Kabupaten Buleleng dan setelah itu barulah dilakukan bimbingan secara berkelompok, mengenai bahanya mengelandang, resiko-resiko yang dapat terjadi, pekerjaan lain yang dapat dilakukan selain mengelandang dan mengemis. Kemudian baru pola penanganan selanjutnya yaitu rehabilitative, dimana pola ini lebih bagaimana proses pemulihan yang selanjutnya mereka akan di pulangkan ke kampung halaman masing-masing yang berada di Kabupaten Karangasem Desa Muntigunung.

3. Persepsi gelandangan dan pengemis terhadap pola penanganan Pemerintah Kabupaten Buleleng tidak semua dipandang baik oleh gelandangan dan pengemis, ada yang menagnggap bahwa perlakuan yang dilakukan oleh Dinas Sosial dan Satpol PP sudah baik, ada juga yang menganggap apa yang di lakukan pada saat merazia harus lebih baik lagi dan perlu dibenahi kembali.

4. Dalam hasil penelitian gelandangan dan pengemis memiliki potensi sebagai sumber belajar sosiologi di SMA kelas XI mengenai permasalahan sosial yang ada di masyarakat. Adapun aspek-aspek di dalam penelitian ini digunakan untuk membahas hasil penelitian yang memiliki potensi sebagai sumber belajar sosiologi di SMA yaitu ranah afektif, kognitif, dan psikomotor. Dari aspek-aspek inilah dapat kita mengetahui hasil penelitian yang memiliki potensi sebagai sumber belajar dalam bentuk rencana pelaksanaan pembelajaran (RPP) 
dalam Bab masalah sosial di masyarakat.

Berdasarkan hasil penelitian yang dilakukan oleh peneliti di lapangan, ada beberapa temuan yang ingin disampaikan penulis sebagai terkait dengan penelitian yang dilakukan, yaitu

1. Bagi guru, pada proses belajar mengajar guru di harapkan untuk lebih kreatif dalam penyampaian materi, sehingga tidak membuat proses belajar mengajar monoton dan peserta didik mudah memahami apa yang disampaikan oleh guru sehingga rasa ingin tau peserta didik dapat berkembang. Penelitian ini diharapkan dapat menjadi sumber refrensi nantinya bagi guru, guru harus memberikan contoh pada kehidupan nyata agar lebih mudah di fahami oleh peserta didik, dan peserta didik lebih peka terhadap apa yang mereka lihat dan meningkatkan kepekaan peserta didik terhadap apaa yang mereka jumpai.

2. Bagi peserta didik sendiri di harapkan pada saat proses pembelajaran fokusnya tidak hanya pada sumber belajar saja, seperti buku paket maupun LKS melainkan peserta didik lebih peka terhadap masalah yang ada di lingkungan sekitar mereka, agar penegtahuannya berkembang dan lebih kritis dalam melihat fenomena-fenomena sosial di sekitarnya.

3. Bagi Pemerintah khususnya Dinas Sosial dan Satpol PP agar lebih meningkatkan pola penagangan yang ditujukan oleh gelandangan dan pengemis di kota Singaraja, lebih memberdayakan, memberikan pelatihan, dan memberikan lapangan pekerjaan untuk mereka agar hidupnya lebih layak lagi kedepannya.

4. Bagi Jurusan Pendidikan Sosiologi, penelitian ini di harapkan dapat dijadikan refrensi dalam kegiatan perkuliahan dalam menambah wawasan tentang keberadaan gelandangan dan pengemis sebagai masalah sosial yang kita hadapi bersama bukan hanya tugas dari Dinas Sosial maupun Satpol PP.

5. Bagi penulis, bahwasannya penelitian ini sangat jauh dari kata sempurna, sehingga diperlukannya kritik dan saran dari pembaca karena dengan adanya hal tersebut dalam membuat tulisan ini menjadi lebih sempurna, dan untuk penulis lain penelitian ini di harapkan dapat menambah wawasan ketika membaca penelitian ini dan ketika peneliti lain melakukan penelitian sejenis dapat mampu melengkapi kekurangan dari penelitian ini.

\section{UCAPAN TERIMAKASIH}

Dalam penelitian ini, peneliti mengucapkan terima kasih kepada Rektor Undiksha, Bapak Dekan FHIS, Bapak Dr. I Ketut Margi, M.Si selaku Dosen Pembimbing I , Bapak I Gusti Arya Suta Wirawan, M.Hum M.Si selaku Dosen Pembimbing II, Ibu Dr. Luh Putu Sendratari, M.Hum, selaku Dosen Penguji, Kepala Dinas Sosial Kabupaten Buleleng, Kepala Satpol PP Kabupaten Buleleng, gelandangan dan pengemis dan Guru Sosiologi SMA N 1 Sukasada Singaraja yang telah bersedia memberikan data yang dibutuhkan, serta pihak-pihak yang tidak bisa disebutkan satu per satu yang telah memberikan kontribusi besar dalam penelitian ini.

\section{Daftar Pustaka}

Ahmad, Mahfur. 2010. Strategi Kelangsungan Hidup GelandanganPengemis (Gepeng). Peaklongan: Jurnal Penelitian. Vol. 7 No. 2.

LP3ES. 1986. Gelandangan. Jakarta: LP3ES Jakarta.

\section{Muslim. 2013. Penanggulangan Pengemis dan Gelandangan di Kota Pekanbaru. Jurnal El-Riyasah.Vol. 4 No. $1 \mathrm{HIm}$. 24-35.}

Rohmaul, Yudi. 2013. Persepsi dan Sikap Masyarakat Terhadap Penanggalan 
e-Journal Pendidikan Sosiologi Universitas Pendidikan Ganesha

Jurusan Sejarah, Sosiologi dan Perpustakaan (Volume 2, Nomor 1, Tahun 2020)

\begin{abstract}
Jawa Dalam Penentuan Waktu
Pernikahan (Studi Kasus Desa

Jonggrang Kecamatan Barat

Kabupaten Magetan Tahun 2013).

Jurnal. Vol. 5 No. 1.

undang-undang nomor 13 tahun

2014 tentang penanganan fakir

miskin.
\end{abstract}

